\title{
EFEK IKLIM KERJA PANAS PADA RESPON FISIOLOGIS TENAGA KERJA DI RUANG TERBATAS
}

\author{
HEAT STRESS EFFECTS ON PHYSIOLOGICAL RESPONSES OF WORKERS IN \\ CONFINED SPACE
}

\author{
Jesika Wulandari, Meirina Ernawati \\ Departemen Keselamatan dan Kesehatan Kerja \\ Fakultas Kesehatan Masyarakat Universitas Airlangga \\ E-mail: jesika.wulandari-2015@fkm.unair.ac.id
}

\begin{abstract}
Heat stress can cause physiological responses such us increased body temperature, pulse rate and blood pressure and also weight loss. The aim of this study is to analyze the physiological responses of workers in confined space heater PT Nippon Shokubai Indonesia. This was an observational study with cross-sectional design. The sample was all of population (10 workers). Data were collected by measuring heat stress (WBGT and physiological responses before and after working. The result of heat stress measurement showed that average of $W B G T$ was $34.9^{\circ} \mathrm{C}$ (above the Threshold Limit Value). The workload of the workers was in the heavy category $(461.94$ ccal). Worker's work time was in category $0-25 \%$. The result showed that the average body temperature before working was $36.73^{\circ} \mathrm{C}$ and after working was $38.13^{\circ} \mathrm{C}$. The average pulse rate before working was 90.85 beats per minute and after working was 96.1 beats per minutes. The average systolic and diastolic blood pressure before working were $124.85 \mathrm{mmHg}$ and $72.05 \mathrm{mmHg}$ and the average after working were $126.05 \mathrm{mmHg}$ and $72.45 \mathrm{mmHg}$. On the other hand, the average weight before working was $59.58 \mathrm{~kg}$ and after working is $58.3 \mathrm{~kg}$. There were differences on the results of body temperature, pulse rate, blood pressure and weight before and after working in CS heater.
\end{abstract}

Keywords: heat stress, physiological response, confined space workers

\begin{abstract}
ABSTRAK
Iklim kerja panas dapat menyebabkan respons fisiologis seperti peningkatan suhu tubuh, denyut nadi, tekanan darah dan juga penurunan berat badan. Tujuan dari penelitian ini adalah untuk menganalisis respons fisiologis tenaga kerja akibat iklim kerja panas di confined space heater PT. Nippon Shokubai Indonesia. Penelitian ini bersifat observasional dengan desain cross-sectional. Besar sampel adalah keseluruhan populasi yaitu 10 orang. Data didapatkan dari pengukuran mengukur iklim kerja panas (ISBB) dan respons fisiologis sebelum dan sesudah bekerja. Hasil pengukuran iklim kerja panas menunjukkan bahwa rerata nilai ISBB sebesar $34,9^{\circ} \mathrm{C}$ sehingga telah melebihi Nilai Ambang Batas dengan beban kerja berat yaitu 461,94 kkal dan kategori waktu kerja 0-25\%. Hasil menunjukkan bahwa rerata suhu tubuh sebelum bekerja adalah $36,73^{\circ} \mathrm{C}$ dan sesudah bekerja adalah $38,13^{\circ} \mathrm{C}$. Rerata denyut nadi sebelum bekerja adalah 90,85 denyut per menit dan sesudah bekerja adalah 96,1 denyut per menit. Kemudian rerata tekanan darah sistolik dan diastolik sebelum bekerja adalah 124,85 mmHg dan 72,05 mmHg, dan rerata sesudah bekerja adalah 126,06 mmHg dan 72,45 mmHg. Selain itu rerata berat badan sebelum bekerja adalah $59,85 \mathrm{~kg}$ dan sesudah bekerja adalah $58,3 \mathrm{~kg}$. Oleh karena itu, terdapat perbedaan antara suhu tubuh, denyut nadi, tekanan darah (sistolik dan diastolik) dan berat badan sebelum dan sesudah bekerja di CS heater.
\end{abstract}

Kata kunci: iklim kerja panas, respons fisiologis, pekerja ruang terbatas

\section{PENDAHULUAN}

Undang-Undang Republik Indonesia Nomor 1 Tahun 1970 tentang Keselamatan Kerja pada pasal 1 ayat 1 menjelaskan bahwa yang dimaksudkan dengan tempat kerja adalah ruangan atau lapangan, tertutup atau terbuka, bergerak atau tetap, yang menjadi tempat tenaga kerja atau sering dimasuki oleh tenaga kerja untuk keperluan suatu usaha dan sumber-sumber bahaya. Sumber bahaya di tempat kerja pun cukup beragam, salah satunya adalah bahaya fisik berupa iklim kerja panas. Penggunaan berbagai alat dan mesin serta material dalam proses produksi telah menjadi salah satu sumber iklim kerja panas bagi tenaga kerja yang dapat dijumpai di berbagai industri di Indonesia (Ramli, 2013). 
Keselamatan dan Kesehatan Kerja (K3) sendiri mengandung makna perlindungan bagi tenaga kerja yang merupakan aset penting dan berharga bagi organisasi dari terjadinya kecelakaan kerja (KK) dan penyakit akibat kerja (PAK) (Ramli, 2013). Hal tersebut seperti yang tercantum pada UU Republik Indonesia Nomor 13 Tahun 2003 tentang Ketenagakerjaan. Sehingga diperlukannya lingkungan kerja yang aman, sehat dan nyaman yang mendukung tenaga kerja melaksanakan pekerjaannya dan mencegah terjadinya KK dan PAK guna mewujudkan produktivitas kerja yang optimal (Suma'mur, 2014).

Iklim kerja adalah kombinasi dari suhu udara, kelembapan udara, kecepatan aliran udara dan panas radiasi (Suma'mur, 2014). Iklim kerja panas bermula dari munculnya energi panas yang berasal dari sumber panas yang dipancarkan langsung atau melalui perantara dan masuk ke lingkungan kerja, dan menjadi tekanan panas sebagai beban tambahan bagi tenaga kerja (Soeripto, 2008). Hal tersebut dapat memperburuk kondisi kesehatan dan stamina tenaga kerja bila ditambah dengan beban kerja fisik yang berat (Vanani, 2010). Sehingga tenaga kerja tersebut akan memerlukan energi yang lebih besar dibandingkan dengan tenaga kerja yang bekerja di lingkungan kerja dengan suhu nyaman yaitu $24^{\circ} \mathrm{C}$ sampai dengan $26^{\circ} \mathrm{C}$. Selain itu lingkungan kerja dengan suhu tinggi lebih banyak menimbulkan permasalahan dibandingkan dengan lingkungan kerja dengan suhu rendah karena manusia lebih mudah melindungi diri dari pengaruh suhu rendah disbanding suhu tinggi (Suma'mur, 2014).

ACGIH (2015) telah menentukan parameter untuk mengevaluasi iklim kerja panas dengan WBGT (Wet Bulb Globe Temperature) atau pada Permenakertrans Nomor 13 Tahun 2011 disebut dengan ISBB (Indeks Suhu Basah dan Bola).

Apabila tenaga kerja terpapar oleh panas melebihi Nilai Ambang Batas (NAB) yang diperkenankan maka dapat menimbulkan terjadinya penyakit akibat kerja dan kecelakaan kerja yang berdampak pada menurunnya produktivitas kerja. Iklim kerja panas dapat menyebabkan gangguan baik fisiologis maupun psikologis pada tenaga kerja (Soedirman dan Suma'mur, 2014). Respon fisiologis yang terjadi antara lain adalah vasodilatasi, peningkatan denyut nadi dan suhu tubuh inti. Chanlet dalam Soedirman dan Suma'mur (2014) juga menyebutkan bahwa respons fisiologis dapat diukur dengan peningkatan kehilangan keringat, denyut nadi dan suhu tubuh inti. Tenaga kerja yang terpapar oleh panas secara terus menerus dapat menyebabkan terjadinya heat rash, heat cramp, heat syncope, heat exhaustion, heat stroke, malaria, dehidrasi dan hipertermia (Soedirman dan Suma'mur, 2014).

Berdasarkan data dari OSHA (2014), Centers for Disease Control and Prevention pada tahun 2012-2013 terdapat banyak kasus pada pekerja yang terpapar panas. Dalam 13 kasus terdapat pekerja meninggal, 7 kasus dimana pekerja mengalami gejala heat strain dengan beban kerja sedang dan berat. Pada penelitian Rahardian (2016) di PT X Sidoarjo diketahui bahwa iklim kerja di area BRF dan TFH telah melebihi NAB yang diperkenankan yaitu $34,6^{\circ} \mathrm{C}$ dan $34,5^{\circ} \mathrm{C}$ dengan beban kerja berat. Pada keadaan tersebut terdapat hubungan antara tekanan panas dengan peningkatan tekanan darah dan denyut nadi dimana semakin tinggi tekanan panas maka semakin meningkat denyut nadi dan tekanan darah tenaga kerja.

Sama halnya dengan penelitian Pradana, dkk (2016) diketahui bahwa di lingkungan kerja panas bagian mesin PT. PLN (Persero) Kalimantan Barat terdapat peningkatan tekanan darah sistolik, diastolik dan denyut nadi sebelum dan sesudah terpapar panas berdasarkan analisis data dengan uji statistik Wilcoxon dengan tingkat kepercayaan 95\%.

PT Nippon Shokubai Indonesia merupakan perusahaan Petrokimia dengan salah satu hasil produksinya yaitu Super Absorbent Polymer (SAP) yang digunakan sebagai bahan baku disposable diapers atau popok sekali pakai. Salah satu mesin dalam proses produksi di SAP Plant adalah heater yang memiliki temperatur saat beroperasi mencapai $\pm 200^{\circ} \mathrm{C}$. Dilakukan pembersihan kerak secara rutin setiap tahun supaya kinerja mesin tersebut selalu prima sehingga heater akan menjadi confined space (CS) bagi tenaga kerja dengan temperatur yang tinggi.

Tenaga kerja yang bertugas merupakan tim khusus dari Production Department dengan rutinitas bekerja rata-rata selama 4 jam. Pekerja akan bergantian masuk ke dalam CS dengan daya tahan waktu untuk bekerja bagi setiap tenaga kerja berbeda-beda.

Adanya paparan iklim kerja panas tersebut dapat menimbulkan dampak bagi fisiologis tenaga kerja seperti peningkatan suhu tubuh, tekanan darah dan denyut nadi. Ditambah pula dengan area kerja yang berupa CS dengan kadar oksigen yang minimum. Berdasarkan wawancara dengan pihak PT. NSI, belum dilakukan pemeriksaan respons fisiologis tenaga kerja yang terpapar panas di CS sebelumnya. 
Berdasarkan data dari klinik perusahaan banyak tenaga kerja yang mengeluh kelelahan, merasa dehidrasi, mudah pusing hingga terdapat yang mengalami kram pada otot perut setelah bekerja dengan paparan panas. Tenaga kerja memiliki karakteristik yang berbeda sehingga kemampuan tubuh menjaga keseimbangan panas pun juga berbeda.

Berdasarkan identifikasi masalah tersebut, maka akan dilakukan pengukuran iklim kerja panas dengan parameter ISBB di area CS heater, pemeriksaan respons fisiologis tenaga kerja sebelum dan sesudah terpapar panas dan menganalisis antara faktor individu tenaga kerja untuk mengetahui apakah faktor tersebut ikut berperan memengaruhi respons fisiologis tenaga kerja. Sehingga dengan adanya penelitian tersebut didapatkan upaya pengendalian yang tepat di area CS heater.

\section{METODE}

Penelitian ini termasuk dalam rancang penelitian observasional karena data yang diperoleh tanpa adanya perlakuan pada variabel yang akan diteliti yaitu pengukuran iklim kerja panas, beban kerja dan respons fisiologis tenaga kerja sebelum dan sesudah terpapar panas. Berdasarkan cara analisis data termasuk dalam penelitian deskriptif. Berdasarkan dimensi waktunya, penelitian ini menggunakan cross-sectional, variabel penelitian diukur dalam satu periode waktu.

Populasi penelitian ini adalah seluruh tenaga kerja yang melakukan cleaning di dalam CS heater yaitu sebanyak 10 orang tenaga kerja. Sampel dalam penelitian ini diperoleh dengan metode total sampling sehingga besar sampel adalah 10 orang tenaga kerja.

Lokasi penelitian dilakukan di PT. Nippon Shokubai Indonesia yang terletak di Jalan Raya Anyer KM 122 Kawasan Industri Panca Puri Ciwandan, Cilegon Banten. Unit yang dilakukan penelitian adalah unit heater yang terletak di Super Absorbent Polymer Plant. Waktu pengambilan data penelitian ini dilaksanakan pada tanggal 27 April sampai dengan 15 Mei 2015.

Variabel yang diteliti yaitu iklim kerja, beban kerja, waktu kerja dan respons fisiologis meliputi suhu tubuh, tekanan darah, denyut nadi dan berat badan.

Pengumpulan data primer dilakukan dengan pengukuran iklim kerja dengan alat Thermal Environment Monitor QUESTemp 34, pemeriksaan denyut nadi dan tekanan darah dengan instrumen Automatic Blood Pressure Monitor Omron HEM7117, dan pemeriksaan suhu tubuh dengan digital thermometer. Selain itu juga dilakukan observasi langsung untuk mengetahui beban kerja berdasarkan SNI 7269-2009 serta melalui penyebaran kuesioner tentang faktor individu tenaga kerja. Sedangkan data pendukung yaitu data sekunder diperoleh dari dokumen-dokumen perusahaan meliputi profil perusahaan, proses dan hasil produksi SAP, kebijakan K3 dan peta perusahaan.

Data yang diperoleh akan diolah dan dianalisis secara deskriptif dalam bentuk tabel distribusi frekuensi mengenai faktor individu dari responden penelitian. Selain itu, dengan grafik yang menunjukkan respons fisiologis tenaga kerja sebelum dan sesudah bekerja di CS heater.

\section{HASIL}

\section{Gambaran Umum PT. NSI}

PT. Nippon Shokubai Indonesia (NSI) adalah PMA (Penanaman Modal Asing) Jepang yang merupakan perusahaan manufaktur pertama di Asia Tenggara yang memproduksi Acrylic Ester (AE) dan Acrylic Acid (AA). PT Nippon Shokubai Indonesia merupakan perusahaan manufaktur pertama di Indonesia yang memproduksi Super Absorbent Polymer (SAP) yang akan dipakai untuk bahan baku dari disposable diapers atau popok sekali pakai. Produk ini dapat digunakan untuk anak-anak, remaja, dewasa dan lanjut usia.

PT. Nippon Shokubai Indonesia dan seluruh tenaga kerjanya dengan bekal konsep "TechnoAmenity" yang memberikan kemakmuran dan kenyamanan melalui inovasi teknologi. NSI bertekad untuk mengelola LHK3 (Lingkungan Hidup, Keselamatan dan Kesehatan Kerja) sebagai usaha terpadu sesuai dengan misi perusahaan seperti menaati peraturan LHK3, evaluasi berkesinambungan sistem LHK3, melindungi lingkungan dan memelihara kondisi kerja yang aman, sehat dan ramah lingkungan.

\section{Faktor Individu Tenaga Kerja}

Seluruh tenaga kerja yang bekerja di CS heater berjenis kelamin laki-laki. Selain itu diperoleh pula data responden seperti umur, masa kerja, status gizi, kebiasaan merokok dan konsumsi cairan dari tenaga kerja sebagai berikut: 
Tabel 1. Distribusi Umur Tenaga Kerja

\begin{tabular}{ccc}
\hline Umur (Tahun) & Jumlah (Orang) & Persentase (\%) \\
\hline $18-20$ & 1 & 10 \\
$21-23$ & 6 & 60 \\
$24-27$ & 3 & 30 \\
\hline Jumlah & 10 & 100 \\
\hline
\end{tabular}

Tabel 2. Distribusi Masa Kerja Tenaga Kerja

\begin{tabular}{ccc}
\hline Masa Kerja & Jumlah (Orang) & Persentase (\%) \\
\hline$\leq 3 \mathrm{Th}$ & 5 & 50 \\
$4-6 \mathrm{Th}$ & 3 & 30 \\
$\geq 7 \mathrm{Th}$ & 2 & 20 \\
\hline Jumlah & 10 & 100 \\
\hline
\end{tabular}

Tabel 3. Distribusi Status Gizi Tenaga Kerja

\begin{tabular}{ccc}
\hline Status Gizi & Jumlah (Orang) & Persentase (\%) \\
\hline Kurus & 3 & 30 \\
Normal & 5 & 50 \\
Gemuk & 2 & 20 \\
\hline Jumlah & 10 & 100 \\
\hline
\end{tabular}

Tabel 4. Distribusi Kebiasaan Merokok Tenaga Kerja

\begin{tabular}{ccc}
\hline $\begin{array}{c}\text { Kebiasaan } \\
\text { Merokok }\end{array}$ & Jumlah (Orang) & Persentase (\%) \\
\hline Ya & 3 & 30 \\
Tidak & 7 & 70 \\
\hline Jumlah & 10 & 100 \\
\hline
\end{tabular}

Berdasarkan Tabel 1 menunjukkan bahwa kelompok umur dengan tenaga kerja terbanyak yaitu 6 orang $(60 \%)$ adalah kelompok umur tenaga kerja dengan umur 21-23 tahun.

Merujuk pada Tabel 2 diketahui bahwa kelompok masa kerja $\leq 3$ tahun merupakan kelompok dengan tenaga kerja terbanyak yaitu 5 orang $(50 \%)$.

Berdasarkan Tabel 3 diketahui bahwa tenaga kerja paling banyak memiliki status gizi normal yaitu sebanyak 5 orang tenaga kerja (50\%).

Merujuk pada Tabel 4 diketahui bahwa tenaga kerja yang tidak merokok adalah sebanyak 7 orang $(70 \%)$.
Tabel 5. Distribusi Konsumsi Cairan Tenaga Kerja

\begin{tabular}{ccc}
\hline $\begin{array}{c}\text { Konsumsi } \\
\text { Cairan }\end{array}$ & Jumlah (Orang) & Persentase (\%) \\
\hline $\begin{array}{c}\text { Tidak Minum } \\
\text { Kurang } \\
(\leq 1 \text { botol })\end{array}$ & 5 & 50 \\
\hline Jumlah & 5 & 50 \\
\hline
\end{tabular}

Tabel 6. Iklim Kerja Panas di Confined Space

\begin{tabular}{|c|c|c|c|c|c|}
\hline Titik & $\begin{array}{l}\text { SBa } \\
\left({ }^{\circ} \mathrm{C}\right)\end{array}$ & $\begin{array}{c}\text { SK } \\
\left({ }^{\circ} \mathrm{C}\right)\end{array}$ & $\begin{array}{l}\text { SBo } \\
\left({ }^{\circ} \mathrm{C}\right) \\
\end{array}$ & $\begin{array}{l}\text { RH } \\
(\%)\end{array}$ & $\begin{array}{l}\text { ISBB } \\
\left({ }^{\circ} \mathrm{C}\right)\end{array}$ \\
\hline \multicolumn{6}{|c|}{ Heater $1 \mathrm{CA}$} \\
\hline \multirow[t]{2}{*}{ Titik 1} & 29,9 & 39,4 & 43,9 & 44 & 33,0 \\
\hline & 27,8 & 37,4 & 38,0 & 52 & 31,1 \\
\hline \multirow[t]{2}{*}{ Titik 2} & 29,1 & 41,8 & 43,9 & 42 & 33,9 \\
\hline & 38,2 & 41,7 & 43,4 & 50 & 33,7 \\
\hline \multicolumn{6}{|c|}{ Heater 2 CA } \\
\hline \multirow[t]{2}{*}{ Titik 1} & 31,2 & 40,5 & 48,9 & 46 & 35,3 \\
\hline & 27,9 & 36,7 & 37,0 & 50 & 31,0 \\
\hline \multirow[t]{2}{*}{ Titik 2} & 53,0 & 33,4 & 56,5 & 28 & 42,5 \\
\hline & 31,0 & 46,6 & 48,0 & 33 & 38,9 \\
\hline Rata & 33,5 & 39,7 & 45,0 & 43,13 & 34,9 \\
\hline
\end{tabular}

Berdasarkan Tabel 5 diketahui bahwa sebanyak 5 orang pekerja $(50 \%)$ pekerja tidak mengonsumsi cairan saat bekerja dan sebesar 5 orang pekerja (50\%) memiliki kategori kebiasaan konsumsi cairan kurang dengan ukuran botol $600 \mathrm{cc}$ atau $600 \mathrm{ml}$.

\section{Iklim Kerja Panas di Confined Space}

Merujuk pada Tabel 6, diketahui bahwa rerata suhu basah alami (SBa) di CS heater adalah $33,5^{\circ} \mathrm{C}$, suhu kering (SK) adalah sebesar $39,7^{\circ} \mathrm{C}$ dan rerata suhu bola (Sbo) adalah $45^{\circ} \mathrm{C}$. Selanjutnya rerata kelembapan udara (RH) adalah sebesar 43,13\%. Indeks Suhu Basah dan Bola (ISBB) di CS heater adalah sebesar $34,9^{\circ} \mathrm{C}$.

Merujuk pada Tabel 6, diketahui bahwa nilai rerata Indeks Suhu Basah dan Bola (ISBB) di CS heater adalah sebesar $34,9^{\circ} \mathrm{C}$

\section{Waktu Kerja Tenaga Kerja}

Dari Tabel 7 maka didapatkan perhitungan:

$\begin{aligned} \text { Rerata waktu kerja } & =\frac{(20,8+10+27+10,5)}{4} \\ & =18,7 \text { menit }\end{aligned}$ 
Tabel 7. Waktu Kerja Tenaga Kerja

\begin{tabular}{ccccc}
\hline \multirow{2}{*}{ Responden } & \multicolumn{4}{c}{ Waktu Kerja (Menit) } \\
\cline { 2 - 5 } & Jam 1 & Jam 2 & Jam 3 & Jam 4 \\
\hline 1 & 12 & 19 & 44 & 17 \\
2 & 21 & 12 & 41 & 12 \\
3 & 20 & 9 & 24 & 19 \\
4 & 12 & 19 & 44 & 17 \\
5 & 11 & 0 & 30 & 6 \\
6 & 13 & 12 & 15 & 20 \\
7 & 31 & 5 & 11 & 8 \\
8 & 13 & 29 & 28 & 6 \\
9 & 56 & 7 & 49 & 0 \\
10 & 19 & 10 & 27 & 0 \\
\hline Rerata & 20,8 & 10 & 27 & 10,5 \\
\hline
\end{tabular}

Berdasarkan hasil perhitungan diketahui bahwa rerata waktu kerja tenaga kerja adalah selama 18,7 menit dengan waktu istirahat selama 41,3 menit dan termasuk waktu kerja $0-25 \%$.

\section{Beban Kerja Tenaga Kerja}

Berdasarkan Standar Nasional Indonesia (SNI) 7269-2009 pekerjaan di CS heater termasuk dalam pekerjaan posisi duduk dengan menggunakan gerakan tangan kategori 2 yaitu membersihkan kerak di CS heater, dan termasuk dalam pekerjaan posisi duduk dengan satu tangan kategori 1 menata blower dan memberi penerangan ke dalam CS heater.

Diketahui bahwa rerata total BK tenaga kerja adalah 461,94 kkal per jam. Berdasarkan Standar

Tabel 8. Beban Kerja Tenaga Kerja

\begin{tabular}{cccc}
\hline $\begin{array}{c}\text { Rerata BK } \\
\text { (kkal/jam) }\end{array}$ & $\begin{array}{c}\text { MB } \\
\text { (kkal) }\end{array}$ & $\begin{array}{c}\text { Total BK } \\
\text { (kkal/jam) }\end{array}$ & Ket. \\
\hline 467,18 & 56 & 523,18 & Berat \\
425,25 & 83 & 508,25 & Berat \\
295,47 & 49 & 344,47 & Berat \\
543,00 & 43 & 586,00 & Berat \\
297,71 & 58 & 355,71 & Berat \\
432,95 & 55 & 487,95 & Berat \\
413,25 & 61 & 474,25 & Berat \\
430,94 & 44 & 474,94 & Berat \\
407,25 & 92 & 499,25 & Berat \\
307,38 & 58 & 365,38 & Berat \\
\hline \multicolumn{2}{c}{ Rerata Total BK } & 461,94 & Berat \\
\hline
\end{tabular}

Nasional Indonesia 7269-2009 dan Keputusan Menteri Tenaga Kerja dan Transmigrasi Republik Indonesia Nomor 13 Tahun 2011 maka beban kerja tenaga kerja di CS heater tersebut termasuk dalam kategori berat.

\section{Respons Fisiologis Tenaga Kerja}

Respons fisiologis tenaga kerja meliputi perubahan suhu tubuh, tekanan darah, denyut nadi dan berat badan sebelum dan sesudah bekerja di CS heater.

Berdasarkan Gambar 1 diketahui bahwa rerata suhu tubuh tenaga kerja sebelum dan sesudah bekerja masing-masing adalah $36,73^{\circ} \mathrm{C}$ dan $38,13^{\circ} \mathrm{C}$. Sehingga diketahui bahwa terdapat peningkatan antara suhu tubuh sebelum dan sesudah bekerja akibat iklim kerja panas di CS heater sebesar $1,4^{\circ} \mathrm{C}$ dan peningkatan hingga $>38^{\circ} \mathrm{C}$.

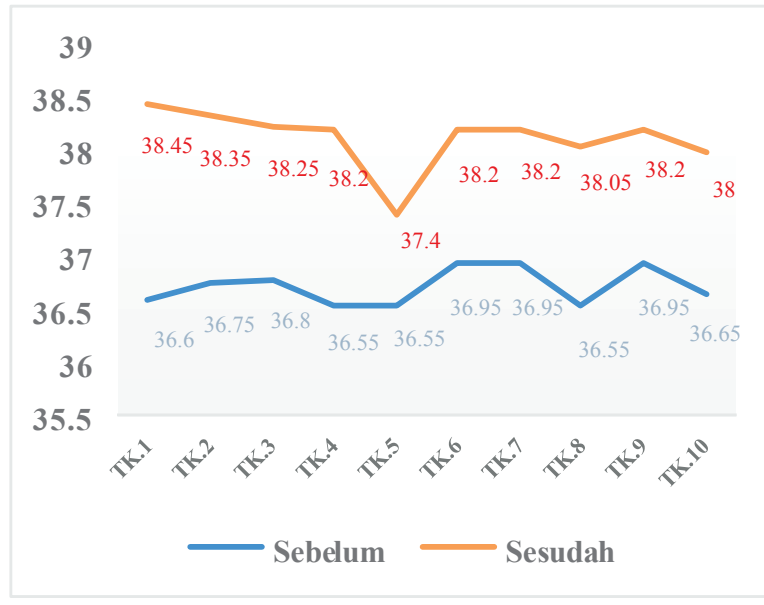

Gambar 1. Grafik Perubahan Suhu Tubuh Sebelum dan Sesudah Bekerja

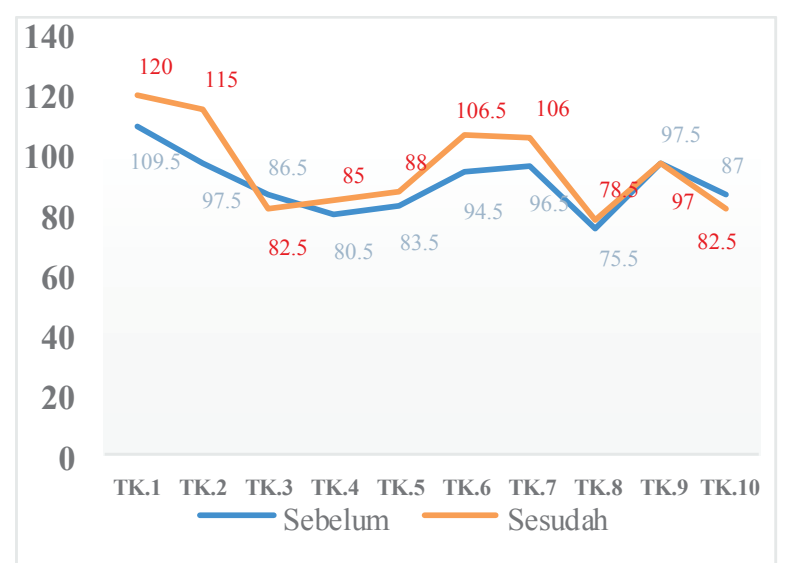

Gambar 2. Grafik Perubahan Denyut Nadi Sebelum dan Sesudah Bekerja 


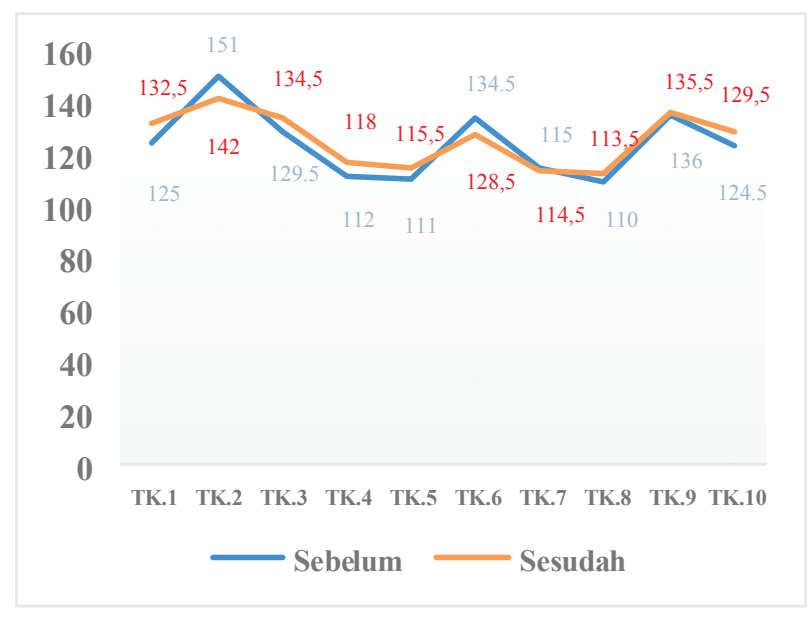

Gambar 3. Grafik Perubahan Tekanan Darah Sistolik Sebelum dan Sesudah Bekerja

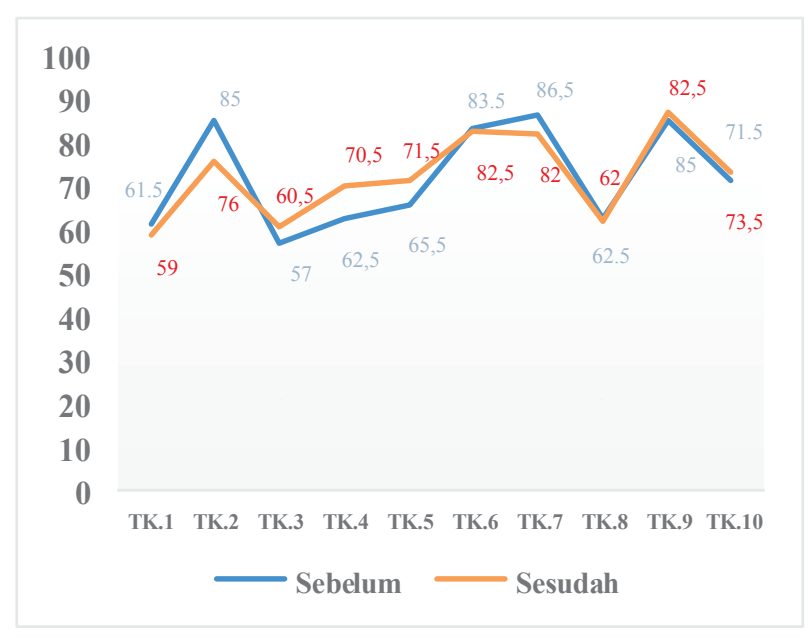

Gambar 4. Grafik Perubahan Tekanan Darah Diastolik Sebelum dan Sesudah Bekerja

Diketahui bahwa rerata hasil pemeriksaan denyut nadi tenaga kerja sebelum bekerja adalah 90,85 denyut per menit sedangkan rerata denyut nadi sesudah bekerja adalah 96,1 denyut per menit. Sehingga diketahui bahwa terdapat peningkatan denyut nadi sebelum dan sesudah bekerja akibat iklim kerja panas di CS heater.

Rerata hasil pemeriksaan tekanan darah sistolik tenaga kerja sebelum bekerja adalah 124,85 mmHg dan rerata sesudah bekerja adalah 126,05 $\mathrm{mmHg}$. Sehingga diketahui bahwa terjadi peningkatan tekanan darah sistolik tenaga kerja sebelum dan sesudah bekerja akibat iklim kerja panas di CS heater.

Pada Gambar 4 diketahui bahwa tekanan darah diastolik tenaga kerja sebelum bekerja adalah 72,05

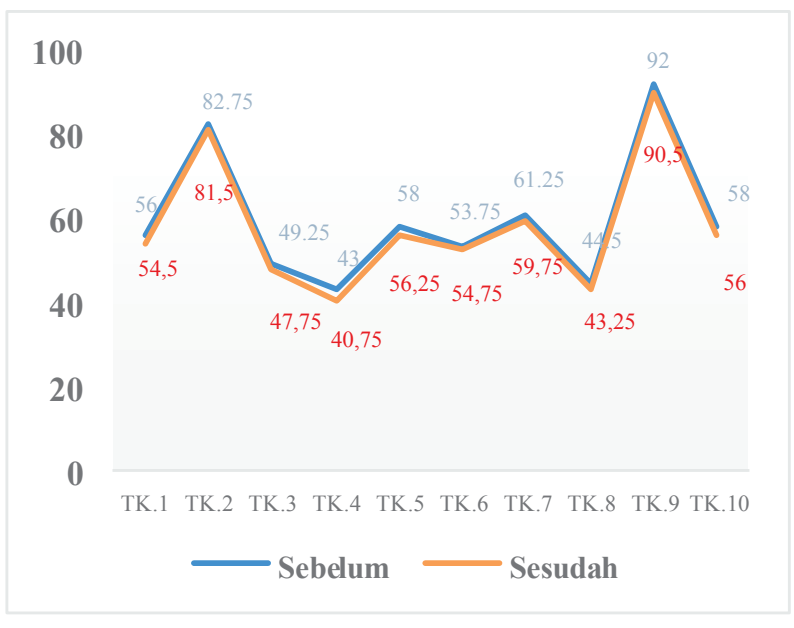

Gambar 5. Grafik Perubahan Berat Badan Sebelum dan Sesudah Bekerja

mmHg dan sesudah bekerja adalah 72,45 mmHg. Hasil pemeriksaan tersebut menunjukkan bahwa terjadi peningkatan tekanan darah diastolik tenaga kerja akibat bekerja dengan paparan iklim kerja panas di CS heater.

Berdasarkan Gambar 5 diketahui rerata hasil pengukuran berat badan tenaga kerja sebelum bekerja sebesar $59,85 \mathrm{~kg}$ dan sesudah bekerja adalah sebesar 58,3 $\mathrm{kg}$. Sehingga dari hasil tersebut diketahui bahwa terdapat penurunan berat badan tenaga kerja sebelum dan sesudah bekerja di CS heater akibat adanya iklim kerja panas.

Berdasarkan Gambar 5 diketahui rerata hasil pengukuran berat badan tenaga kerja sebelum bekerja sebesar 59,85 $\mathrm{kg}$ dan sesudah bekerja adalah sebesar $58,3 \mathrm{~kg}$. Sehingga dari hasil berikut diketahui bahwa terdapat penurunan berat badan tenaga kerja sebelum dan sesudah bekerja di CS heater akibat adanya iklim kerja panas.

\section{PEMBAHASAN}

\section{Faktor Individu Tenaga Kerja}

Tenaga kerja yang bekerja di CS heater seluruhnya berjenis kelamin laki-laki. Laki-laki mempunyai daya tahan tubuh yang lebih baik terhadap panas dibandingkan dengan wanita. Tubuh wanita memiliki jaringan dengan daya konduksi lebih rendah terhadap dingin dan daya konduksi yang lebih besar terhadap panas apabila dibandingkan dengan pria, sehingga wanita akan lebih memberikan reaksi perifer apabila bekerja pada cuaca yang panas. Sehingga, seorang wanita 
lebih tahan terhadap udara dingin daripada udara panas (Soedirman dan Suma'mur, 2015).

Sebagian besar tenaga kerja berada pada rentang umur 21-23 tahun. Umur tenaga kerja yang masih tergolong muda akan memudahkan tenaga kerja tersebut bekerja dengan paparan iklim kerja panas. Suma'mur (2014) menyebutkan bahwa proses menjadi tua diikuti pula dengan berkurangnya kemampuan kerja seseorang karena terjadi perubahan baik secara hormonal maupun kardiovaskuler. Tenaga kerja yang menjadi responden dalam penelitian sebagian besar mempunyai masa kerja $\leq 3$ tahun (50\%). Adiningsih (2013) mengasumsikan bahwa tenaga kerja dengan masa kerja yang lama telah terampil dalam bekerja namun paparan panas yang diterimanya pun semakin besar.

Sebagian besar tenaga kerja memiliki status gizi dalam kategori normal. Tenaga kerja yang status gizinya jelek akan menunjukkan respons yang berlebihan terhadap iklim kerja panas dan hal ini disebabkan oleh karena sistem kardiovaskuler tenaga kerja yang tidak stabil.

Terdapat tenaga kerja yang bekerja di CS heater yang memiliki kebiasaan merokok padahal nikotin dalam rokok dapat merangsang medulla adrenal dengan akibat terjadinya pelepasan katekolamin yang menimbulkan takikardi dan kenaikan tekanan darah (Setiawati, dkk 2007). Aula (2010) menjelaskan pula bahwa efek nikotin menyebabkan perangsangan terhadap hormon epinefrin (adrenalin) yang bersifat memacu peningkatan frekuensi denyut jantung, tekanan darah, kebutuhan oksigen jantung, serta menyebabkan gangguan irama jantung.

Tenaga kerja tidak mengonsumsi cairan saat bekerja di CS heater. Hal tersebut merugikan tenaga kerja karena menurut Suma'mur (2014), pekerjaan yang dilakukan di lingkungan yang panas perlu diperhatikan secara khusus mengenai kebutuhan konsumsi air dan garam sebagai pengganti cairan akibat terjadinya evaporasi dan dapat menyebabkan dehidrasi bagi tenaga kerja.

\section{Waktu Kerja dan Beban Kerja Tenaga Kerja}

Hasil pengukuran beban kerja dengan pedoman SNI 7269-2009 menunjukkan hasil bahwa rerata total beban kerja tenaga kerja di CS heater adalah 461,94 kkal per jam. Berdasarkan Standar Nasional Indonesia (SNI) 7269-2009 tentang Penilaian Beban Kerja Berdasarkan Tingkat Kebutuhan Kalori Menurut Pengeluaran Energi dan Keputusan Menteri
Tenaga Kerja dan Transmigrasi Nomor 13 Tahun 2011 tentang Nilai Ambang Batas Faktor Fisika dan Faktor Kimia di Tempat Kerja maka beban kerja responden di CS heater tersebut termasuk dalam kategori berat.

Suma'mur (2014) menjelaskan bahwa tenaga kerja dapat terhindar dari penyakit akibat kerja dan kecelakaan kerja supaya produktivitas kerja optimal apabila terdapat keseimbangan antara beban kerja dan kapasitas kerjanya.

Diperoleh pula data mengenai rerata waktu kerja setiap jam yaitu selama 18,7 menit. Berdasarkan Keputusan Menteri Tenaga Kerja dan Transmigrasi Nomor 13 Tahun 2011 maka waktu kerja tenaga kerja termasuk dalam pengaturan waktu kerja $0-25 \%$, artinya tenaga kerja bekerja selama 18,7 menit dengan paparan panas dan beristirahat selama 41,3 menit.

\section{Iklim Kerja Panas di CS Heater}

Pengukuran iklim kerja panas dilakukan dengan menggunakan alat Thermal Environment QUESTemp 34 yang dilakukan di 4 titik lokasi. Hasil pengukuran iklim kerja didapatkan bahwa rerata suhu basah adalah $33,5^{\circ} \mathrm{C}$, sedangkan rerata suhu kering adalah $39,7^{\circ} \mathrm{C}$ dan rerata suhu bola adalah $45^{\circ} \mathrm{C}$. Diketahui pula kelembapan udara yaitu sebesar 43,13\%. Indeks Suhu Basah dan Bola (ISBB) di $\mathrm{CS}$ heater adalah $34,9^{\circ} \mathrm{C}$. Berdasarkan Keputusan Menteri Tenaga Kerja dan Transmigrasi Nomor 13 Tahun 2011 bahwa dengan beban kerja berat dan pengaturan waktu kerja kategori $0-25 \%$, dengan nilai ISBB sebesar $34,9^{\circ} \mathrm{C}$ artinya iklim kerja di CS heater telah melebihi Nilai Ambang Batas (NAB) yang ditetapkan yaitu $30,5^{\circ} \mathrm{C}$.

Panas yang dipaparkan di lingkungan kerja dapat menimbulkan tekanan panas yang akan menjadi beban kerja tambahan bagi tenaga kerja (Soeripto, 2008). Iklim kerja panas yang diterima tenaga kerja apabila telah melebihi toleransi yang ditetapkan dapat menimbulkan gangguan fisiologis (Soedirman dan Suma'mur, 2014). Lingkungan kerja dengan suhu yang tinggi merupakan hal yang perlu mendapatkan pengawasan lebih, hal tersebut karena menimbulkan masalah yang lebih banyak dibandingkan dengan lingkungan kerja dengan suhu yang rendah. Hal tersebut karena pada umumnya manusia lebih mudah melindungi diri dari pengaruh suhu rendah dibandingkan dengan suhu yang tinggi (Suma'mur, 2014). 


\section{Respon Fisiologis Tenaga Kerja}

Rerata hasil pemeriksaan suhu tubuh sebelum dan sesudah bekerja pada tenaga kerja yang bekerja di CS heater adalah $36,73^{\circ} \mathrm{C}$ dan $38,13^{\circ} \mathrm{C}$. Sehingga dapat disimpulkan bahwa terdapat peningkatan antara suhu tubuh sebelum dan sesudah bekerja akibat iklim kerja panas di CS heater. Soedirman dan Suma'mur (2014) menyatakan bahwa akumulasi panas dari lingkungan kerja dapat menyebabkan naiknya suhu tubuh yang direfleksikan oleh naiknya suhu rektal dan dengan suhu tubuh mencapai $>38^{\circ} \mathrm{C}$ maka dapat disimpulkan pula bahwa tenaga kerja telah mengalami heat strain.

Sama halnya dengan penelitian Adiningsih (2013) di PT. Aneka Boga Makmur bahwa terdapat perbedaan yang signifikan antara suhu tubuh sebelum dan sesudah bekerja di lingkungan dengan iklim kerja panas dengan nilai signifikansi 0,000 dan $\alpha 0,005$. Rerata perubahan nilai suhu tubuh sebelum dan sesudah bekerja adalah sebesar $0,78^{\circ} \mathrm{C}$ dengan suhu tubuh sebelum bekerja sebesar $37,12^{\circ} \mathrm{C}$ dan sesudah bekerja adalah $37,90^{\circ} \mathrm{C}$.

Hasil pemeriksaan diketahui bahwa rerata hasil pemeriksaan denyut nadi tenaga kerja sebelum bekerja adalah 90,85 denyut per menit sedangkan rerata denyut nadi sesudah bekerja adalah 96,1 denyut per menit. Sehingga dapat disimpulkan bahwa terdapat peningkatan denyut nadi tenaga kerja sebelum dan sesudah bekerja akibat iklim kerja panas di CS heater.

Soedirman dan Suma'mur (2014) menjelaskan tenaga kerja yang terpapar panas akan mengalami peningkatan denyut nadi. Denyut nadi dapat mengalami perubahan karena adanya peningkatan cardiac output atau curah jantung yang diperlukan oleh otot yang sedang bekerja. Selain itu juga karena adanya penambahan strain pada aliran darah karena terpapar iklim kerja panas. Saat tenaga kerja melakukan pekerjaan, akan terjadi peningkatan metabolisme sel-sel otot sehingga aliran darah meningkat untuk proses perpindahan zat-zat makanan dari darah yang dibutuhkan oleh jaringan otot. Semakin tinggi aktivitas maka semakin besar pula kebutuhan untuk menyuplai zat makanan melalui peningkatan aliran darah. Peningkatan curah jantung tersebut akan meningkatkan frekuensi denyut nadi yang akan meningkatkan kinerja jantung untuk mengalirkan darah ke kulit yang bertujuan untuk meningkatkan penguapan keringat dalam rangka mempertahankan suhu tubuh.
Senada dengan hasil penelitian Pradana, dkk (2016), diketahui bahwa rerata denyut nadi sebelum bekerja dengan paparan iklim kerja panas adalah 81,82 denyut per menit dan rerata denyut nadi sesudah bekerja adalah 92,93 denyut per menit. Dengan nilai $p$-value sama dengan 0,000 dan $\alpha$ sebesar 0,005 artinya terdapat perbedaan antara denyut nadi sebelum dan sesudah bekerja akibat iklim kerja panas di PT. PLN (Persero).

Hasil pemeriksaan rerata tekanan darah sistolik tenaga kerja di CS heater sebelum bekerja adalah 124,85 $\mathrm{mmHg}$ sedangkan sesudah bekerja adalah $126,05 \mathrm{mmHg}$ dan rerata tekanan darah diastolik tenaga kerja sebelum bekerja adalah $72,05 \mathrm{mmHg}$ sedangkan rerata sesudah bekerja adalah $72,45 \mathrm{mmHg}$. Sehingga disimpulkan bahwa terjadi peningkatan tekanan darah sistolik dan diastolik tenaga kerja sebelum dan sesudah bekerja akibat iklim kerja panas di CS heater.

Hasil penelitian tersebut sejalan dengan hasil penelitian Larasati (2015) bahwa terdapat kenaikan tekanan darah sistolik dan diastolik setelah bekerja dengan iklim kerja panas. Rerata kenaikan tersebut adalah sebesar 9,95 mmHg untuk tekanan darah sistolik dan sebesar 6,1 $\mathrm{mmHg}$ untuk tekanan darah diastolik.

Respons fisiologis terhadap iklim panas selain suhu tubuh, denyut nadi dan tekanan darah dapat dilihat pula dari banyaknya keringat yang dihasilkan oleh tubuh. Pengeluaran keringat dapat mengakibatkan penurunan berat badan pada tenaga kerja. Kehilangan air sebanyak $1,5 \mathrm{~kg}$ atau lebih dapat mengakibatkan kenaikan denyut nadi dan suhu tubuh dan dehidrasi.

Rerata hasil pengukuran berat badan tenaga kerja sebelum bekerja sebesar 59,85 $\mathrm{kg}$ dan sesudah bekerja adalah sebesar 58,3 kg. Sehingga diketahui bahwa terdapat penurunan berat badan tenaga kerja sebelum dan sesudah bekerja akibat iklim kerja panas di CS heater dengan penurunan berat badan rata-rata $1,55 \mathrm{~kg}$.

\section{SIMPULAN}

Seluruh pekerja berjenis kelamin laki-laki dengan rentang umur terbanyak $21-23$ tahun $(60 \%)$, masa kerja $\leq 3$ tahun $(50 \%)$, status gizi normal $(50 \%)$, tidak memiliki kebiasaan merokok $(70 \%)$. Tenaga kerja tidak memiliki kebiasaan konsumsi cairan selama bekerja di iklim kerja panas (505) dan 
sisanya $(50 \%)$ mengonsumsi cairan dalam jumlah $\leq$ 1 botol ukuran $600 \mathrm{cc}$ atau $600 \mathrm{ml}$.

Seluruh pekerja memiliki beban kerja yang berat dengan rerata jumlah kebutuhan kalori sebesar 461,94 kkal per jam dan waktu kerja termasuk dalam waktu kerja $0-25 \%$ yaitu selama 18,7 menit kerja dan 41,3 menit istirahat.

Nilai Indeks Suhu Basah dan Bola (ISBB) di $\mathrm{CS}$ heater adalah sebesar $34,9^{\circ} \mathrm{C}$. Sehingga dengan jam kerja termasuk kategori 0-25\% dan beban kerja berat maka ISBB di CS heater telah melebihi Nilai Ambang Batas Berdasarkan Peraturan Menteri Tenaga Kerja Nomor 13 Tahun 2011 yaitu 30,5 ${ }^{\circ} \mathrm{C}$.

Hasil pemeriksaan fisiologis menyatakan bahwa terdapat peningkatan dengan rerata suhu tubuh sebelum bekerja $36,73^{\circ} \mathrm{C}$ dan meningkat menjadi $38,13^{\circ} \mathrm{C}$ setelah bekerja, rerata denyut nadi 90,85 denyut per menit dan meningkat menjadi 96,1 denyut per menit. Selain itu rerata tekanan darah sistolik sebelum dan sesudah bekerja adalah 124,85 dan 126,05 $\mathrm{mmHg}$ dan tekanan darah diastolik sebelum dan sesudah bekerja $72,05 \mathrm{mmHg}$ dan 72,45 mmHg. Terjadi pula penurunan berat badan dengan rerata sebelum kerja $9,85 \mathrm{~kg}$ dan sesudah bekerja $58,3 \mathrm{~kg}$.

Sehingga disimpulkan bahwa terdapat respons fisiologis yang terjadi pada tenaga kerja akibat iklim kerja panas. Hal tersebut ditandai dengan adanya perbedaan suhu tubuh, denyut nadi, tekanan darah sistolik, tekanan darah diastolik dan berat badan sebelum dan sesudah bekerja di confined space heater PT Nippon Shokubai Indonesia.

\section{DAFTAR PUSTAKA}

Adiningsih, R. 2013. Faktor yang Memengaruhi Kejadian Heat Strain pada Tenaga Kerja yang Terpapar Panas di PT. Aneka Boga Makmur. The Indonesian Journal of Occupational Safety and Health, 2(2): pp. 145-153.

American Conference of Government Industrial Hygienist (ACGIH). 2015. Threshold Limit Values for Chemical Substances, Physical Agents and Biological Exposure Indices. United States:
ACGIH.

Aula, L.E. 2010. Stop Merokok. Yogyakarta: Gara Ilmu.

Larasati, A.S. 2015. Analisis Perbedaan Suhu Tubuh dan Tekanan Darah Sebelum dan Setelah Terpapar Panas pada Pekerja Area Workshop di PT X. Skripsi. Surabaya: Universitas Airlangga.

Peraturan Menteri Tenaga Kerja dan Transmigrasi Nomor 13 Tahun 2011 Tentang Nilai Ambang Batas Faktor Fisika dan Faktor Kimia di Tempat Kerja. Jakarta: Kementerian Tenaga Kerja dan Transmigrasi RI.

Pradana, T.D., Rochmawati., Sumiati. 2016. Perbedaan Efek Fisiologis pada Pekerja Sebelum dan Sesudah Bekerja di Lingkungan Panas. Jurnal Vokasi Kesehatan, 2(1): pp. 253-258.

Rahadian, R.R. 2016. Hubungan antara Tekanan Panas dan Beban Kerja dengan Peningkatan Denyut Nadi Pekerja pada Area Kerja BRF dan TFH di PT X. Skripsi. Surabaya: Universitas Airlangga.

Setiawati, A., Suyatna, F.D., Gan, S. 2007. Farmakologi dan Terapi. Jakarta: Departemen Farmakologi dan Terapeutik Fakultas Kedokteran Universitas Indonesia.

Soedirman., Suma'mur, P. 2014. Kesehatan Kerja dalam Perspektif Hiperkes dan Keselamatan Kerja. Jakarta: Penerbit Erlangga.

Soeripto, M. 2008. Higiene Industri. Jakarta: Balai FK Universitas Indonesia.

Standar Nasional Indonesia (SNI) 7269-2009 Tentang Penilaian Beban Kerja Berdasarkan Tingkat Kebutuhan Kalori Menurut Pengeluaran Energi. Jakarta: Badan Standardisasi Nasional.

Suma'mur, P. 2014. Higiene Perusahaan dan Kesehatan Kerja (Hiperkes). Jakarta: Sagung Seto.

Vanani, N.S. 2010. Gambaran Tekanan Panas dan Keluhan Subyektif pada Pekerja di Bagian Curing PT. Multistrada Sarana, Tbk. Skripsi. Universitas Airlangga.

Undang-Undang Nomor 1 Tahun 1970 tentang Keselamatan Kerja. 